結＼cjkstart論

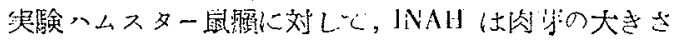

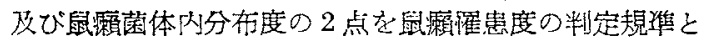
して判断する場合には明らかに発应阻昆析びに治療上多 少にかかわらず見るべき效果が蚛る。

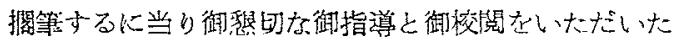
恩師占部教授に感謝の言を表しなす。

\section{主要文献}

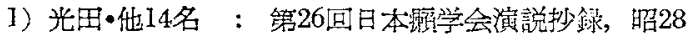

2) 林・他 7 名： "

3)上川!馬鼻：＂，

4) 大西・他6名 : "

5) 谷村他-2名 :

6) 重松・藤源
7) 市原・茒田

8) 徐村·做3名：

9) 安时・他5名：神开医科大学紀要, 4(1),70, 昭28

10）野鳥・优 2 名：第1回日本剩学会西部地方会演説 抄淾 昭 27

11) 西村・河野 : 最新医学, 7 (11)，98, 昭 27

12）机沢・他 3 名：結核研究の進歩，1，42，昭28 （結核交献の抄㳟速報 4(4),21,昭28上り引用)

13）高山・安元：レプラ，22(1)，18，昭28

14) P.J. Colestos: Rev. de la Tuberc. 16(7.8),670 1952 （結核文献の抄淾速報,3(12)50,炤27より引用)

15) Bernard Rubin, G. Lee Hassert, Jr., Bernard G. H. Thomas, and John C. Burke: Am. Rev. Tbc., $65(4), 392,1952$

16) 高山：「レプラ」，22㺼へ近く揭載预定

\title{
EFFECT OF ANTIBIOTICS ON MURINE LEPROSY
}

\section{SHINJI NISHIMURA and MICHIYUKI KONO}

(Leprosy Section, Research Inststute for Microbial Diseases, Osaka University.)

\section{TARO MASUDA}

(Department of Dermatology, Osaka University, Medical Sehool.)

Experimental studies were carried out on the inhibitory action of antibiotics on development of murine leprosy. Those antibiotics, Acidomycin (AM) (Thiazolidone Antibiotics of McLamor et al.), Streptomycin (SM) and Aureomycin (AUM) were studied and the results are presented below.

1. Acidomycin does not have an inhibitory action on the development of murine leprosy. (Fig. 1, 3 and 4)

2. Streptomycin has a moderate inhibitory effect on the development of murine leprosy. (Fig. 2, 3 and 4)

From these results and the results of previous studies chemotherapeutic agents, it is believed that antibiotics which are ineffective in experimental tuberculosis are also ineffective in preventing development of murine leprosy.

\section{癩の化学療法に関する研究 (第13報)}

一鼠瀬に対する抗生物質の影響——

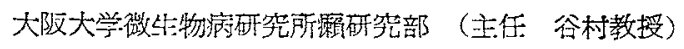

矿村 馚 二 润野通之 
大阪大学医学部皮周科议沓器科教空（主任 谷村教授）

增 田 太 郎

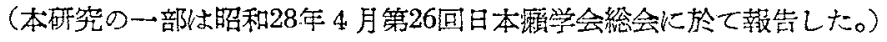

\section{緒}

\section{言}

さきにわれわ机は，旗化学療法に関する一連の研究と して, 鼠瀨に対する諸種化学療法成の作用を检討した が，抗生物貿についてはいるだ手を染めずにいた。然る に最近日本及びアメリカで期せずして同時仁発見された

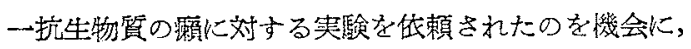
他の抗生物質として Streptomycin 及び*Aureomycin を も選び，先ずとれ等を鼠瀨に用いて，その影響を調ベる ととにした。

さてての新らしい抗生物質とは1952年武田薬品工業1 2) で放線菌の 1 種 Streptomyces acidomyceticus の培養液 から䛣出精製された白色結晶で “Acidomycin”之名付

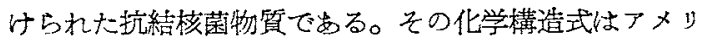
カ Pfizer 社に Mc Lamor 等 ${ }^{3)}$ によつて報告された下記 の Thiazolidone Antibiotics と全く同一のものである。<smiles>O=C(O)CCCCCC1NC(=O)CS1</smiles>

そしててのものは予研梅沢研究室》に括いてる沿ど间 時期に見出されたるのであり，アメリ机に於ては，Pfizer 社の外に Abbot 社, Lederle 社の各研究堂でも和がけ ていたことがあとになつてわかつて来た。ところが実餄 の進むにつれてての物質は in vitro では人型結核菌に対 して Streptomycin に数倍する抗菌力を有し, 動物に対 する毒性す極めて低いもので号つたが，残念ながら in vivo の実験結核では全く効果のないととが明がなつ た。しかしわれわれがこれを鼠制化試みた時期では，ま だ結核動物での実験結果が充分明か比されていなかつた のである。

次に Streptomycin の結核症に対する優れた洽効につ いては多くを述へるまでもない。として既に䎦に用いた

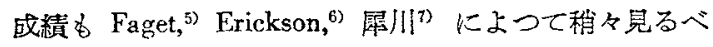
き効果のbるととが報ぜられ，又鼠瀨には Crunberg8, Levadition, 佐藤 ${ }^{(0)}$, 北村 ${ }^{11)}$, 安元 ${ }^{12)}$, 高 ( $^{137}$, Chang ${ }^{14)}$

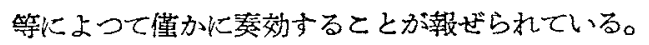

Aureomycin はリケッチ及び一部のヴイールス，クラ 厶陽性及び陰性桿菌にも作用するもので孝るが，結核菌
に対しては㤠んど効力を示さないといわれている

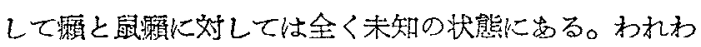
れが敢ててれを実験に加えた理由は，㴼菌，鼠霣菌の発

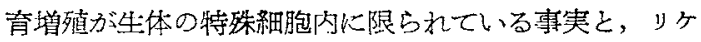
ツチア，ヴイールスの增殖が全く同様の関係にあるとと ろから，或はリケッチア等优対する Auremycin の作用

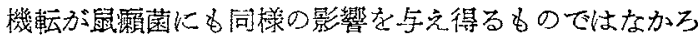
らかと想像したととによる。

以上のよらに的れわれは，放線菌の生虐する挖生物 質，特に結核菌に強く作用する Streptomycin，全く作用 しないといわれる Aureomycin，及び未知（実験当時）の

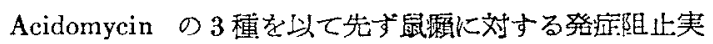
験を試䚺た。以下の所見を述へたい。

\section{実 験 方 法

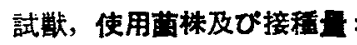

体重 $100 \mathrm{~g}$ 内外の婎性白鼠を撰び鼠瀨菌熊本株の籟腫 生塩水乳剂を20倍, 200 倍, $10^{3}$ 倍, $10^{4}$ 倍に稀积したも の，それぞれ $0.5 \mathrm{cc}$ を各組25匹づつ計 125 匹に皮下注 射した。このよらに接種菌量に段階をもらけたととは，

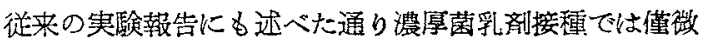

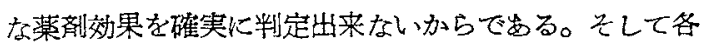
組25匹のうち10匹を Acidomycin (以下 $\mathrm{AM}$ )， 5 炕它 Streptomycin（以下 SM）実験群とし，残りの10Rせは無 処置対招群とした。A Autreomycin (以下 AUM) の㿤験 には AM 及び SM 笑験の成績にか心がみ熊本株源蹅の 200 倍及び $10^{4}$ 倍乳戍の段階とし，その $0.5 \mathrm{cc}$ を15匹つ つ計30匹に皮下注射し，各組とも10p匹 AUM を投与 し，5 匹は無処置対照群とした。

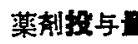

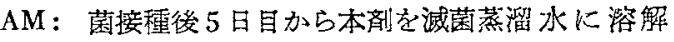
し，1日 $5 \mathrm{mg}$ を 1 週 6 日連用，1日休止の法で 150 日 閔皮下注射した。

$\mathrm{SM}$ ：ジヒドロストレプトマイシン(武田)を用い $\mathrm{AM}$ と同様の方法で $5 \mathrm{mg}$ 皮下注射した。

AUM：接種翌日より可溶性結晶塩酸オーレオマイシ ン錠（レダリー）を密碎し，1日量 pro $\mathrm{kg} 12.5 \mathrm{mg}$ 1 遗 6 日連用，1 日休止の法で経口投与した。本錠剂は 最初滅菌蒸溜水に溶解, 分制注射する計画で岁つたが, 注射後の周所炎症性浮腫强く, 試嘼が著しく衰弱し，た 
めに経山投与を行つた。文本坊を連日投与するときは投

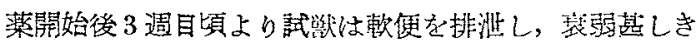
ために 3 週間投与後 1 週間の休薬を設けて反覆投与し to

\section{成鈢判定法：}

櫴腫判定標準を以下の如く定め，30日每に触診によつ てその登症程度の平均值をとつた。

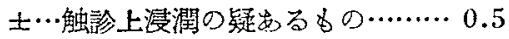

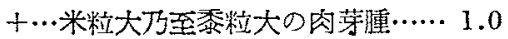

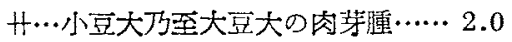

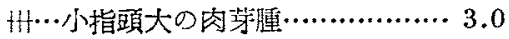

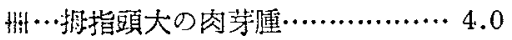

册…鸱畉大以上の肉芽婳………… 5.0

右端の数値は登症程度を表現する便宲上これを設けた ものでむる。

AM 及び SM 実験群は 280 日运, AUM 群は 150 日

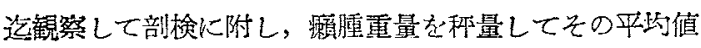
をとつた。

又各淋巴腺及び内贜に於ける鼠瀨菌の分布はチール・ ネールセン染色塗抹標本を作㹕,鏡検の上,次の如き礿蕉 で成績を表示し，その平均值をとつた。(対物レンズ10×， 対眼レンズ10×による拡大による)

上…菌をるつた巨態賥胞が標本面に 1 ケ認められるも の

$+\cdots$ 平均数視野万至 1 視野儿 1 ケ認められるもの $\cdots 2.0$

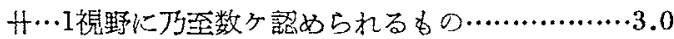

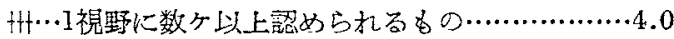

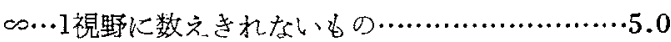

右端の数値は菌の分布程度を表現する便宣上これを設 けたものである。

\section{実 験 成 績}

\section{Acidomycin の発症阻止作用}

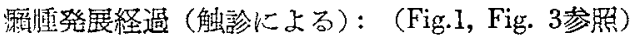

先ず20倍菌乳剂接種組についてその注射群，対照群各

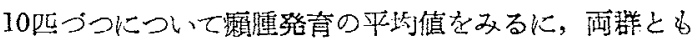
接種15日目垻から政い浸潤を認め，その後日の経つにつ れて籁腫は逐次增大し，121１50日目では AM 注射群 のすが対照群よりも却つて大きく，注射中止後30～60日

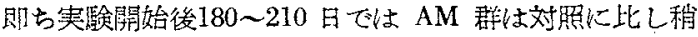
々大きく240２80日目に至り略々同様になつている。即

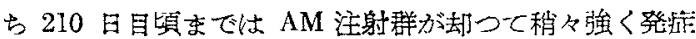
したが，この程度ては他群の例から兒てる注射の大めと

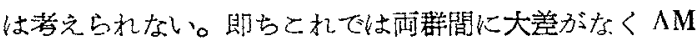

注射の影響がみられない。次に200倍，103倍，104倍， $10^{5}$ 倍倍菌乳剂接種の各組について，それぞれ対照群と 比較してみると，接種菌量の減少につれて発症時期が次

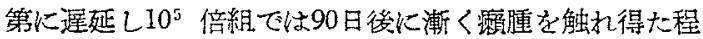
で出るが，何れの組も AM 群と無処置群との間に大差 はなく，時期によつては双方に多少の違いを認めたが，

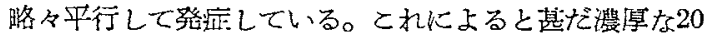

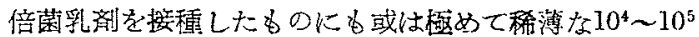
倍菌乳威を接種した白鼠にる AM の影響は全く見られ なかつたといつてよい。

剖検時に括ける㖽腫重量：(Fig. 4. 参照)

$20,10^{3}$ 倍組では $\mathrm{AM}$ 群の平均雷量は対照群より大で むり，200倍，104 倍，105 倍組では AM 群が刘照に比し 稍々小で岕るが，何れの組に於ても耐群間に大差はな い。即斿との所見は前の触診による判定成銈と概社一致 している。

各淋巴腺及び内䐬他於勀る菌分布：（Fig. 4.参照）表 在淋巴腺に於ては AM 群は各組を通して対嬖群に比し 菌分布上大差はない。内期代於ても接䅦菌量の多い20倍 組では AM 群に菌を多く認めているが，200 倍組以下で 忙 AM 群の方が対照よりも菌は少い。何れにしても雨

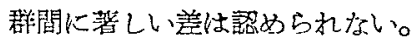

以上菌分布についてみても両群間に略々平行して䔉が 認められるし，好炕よつて仕AM群の方に多く菌を喼め た処り岁る。

\section{Streptomycin $の$ 発症阻止作用}

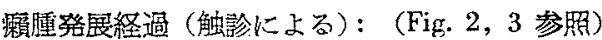

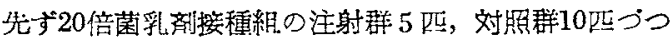

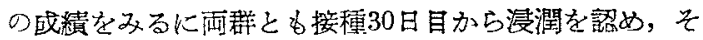
の後日の経つにつれて闭群とも逐次整腫憎大している

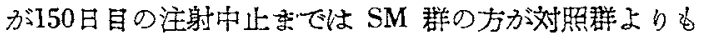
ずつと抑制されている。然るに中止後 1 ケの 180 日目 資よりSM群の方が遥か比增大し 210 280日目では対照 群を倰嘿している。次以 200 倍菌乳剂接種組以下の各組， について雨群を比較する之 SM 群は対炤群より発症時期

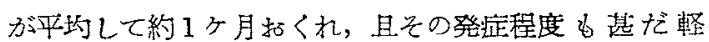
く，明か排制されているととがわかる。としてて执ら の場合150日目注射中止後与発症惊極めて徐々で,200偕, $10^{3}$ 倍，104倍接種では 280 日で漸く大豆大に達したが $10^{5}$ 倍のものでは潮く米粒大に㢸育したに過ぎなかつた。

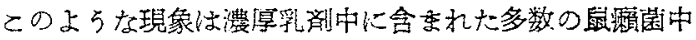
にはSM の作用によく坿六て车き残つたものが何可成り

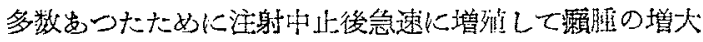

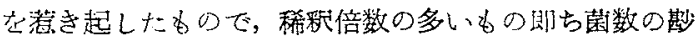




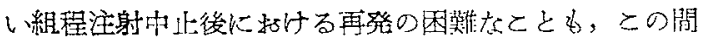
の事情を物語つているものと思ら。

以上要するに甚だ涉厚な菌乳剤を接種したものも SM

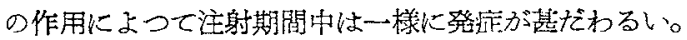
乙かし一旦注射を中止すると接種菌量の多い、20倍荇乳郕 組では急速に增大し210日以降では算処置群よりも却つ
て強く発症した程で点る。然し200 倍以下の各組代於て

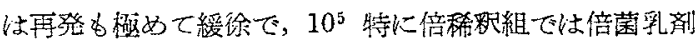
のM 群及び $10^{5}$ 倍然妈置群に比して顕著な差を示して いส้。

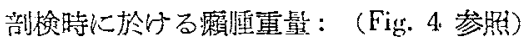

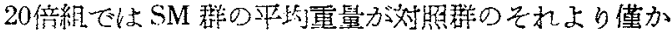

Fig. I Inhibitory Action of Acidomycin on Development of Murine Leprosy.

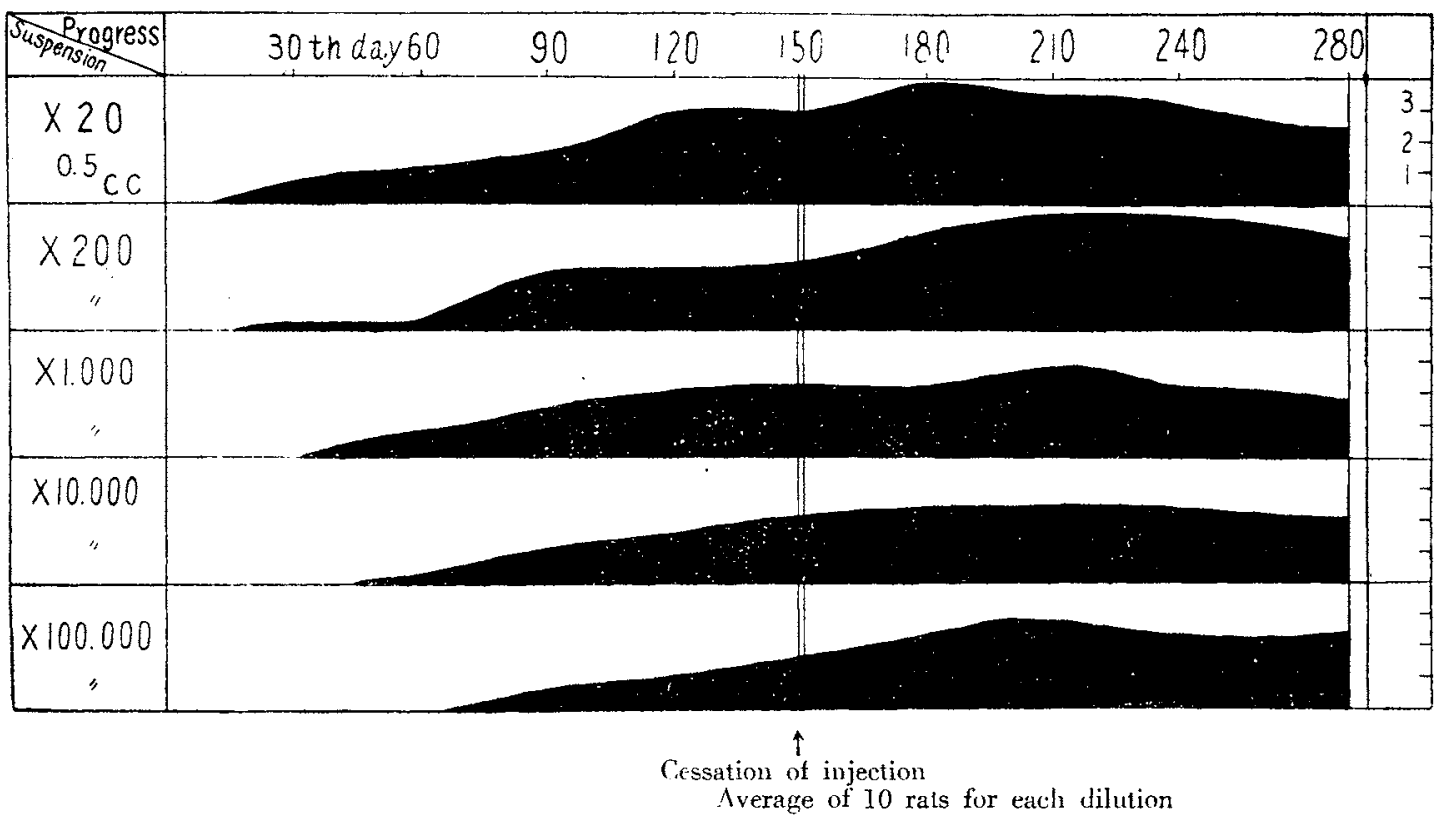

Fig. 2 Inhibitory Action of Streptmpcin on Development of Murine Lebrosy.

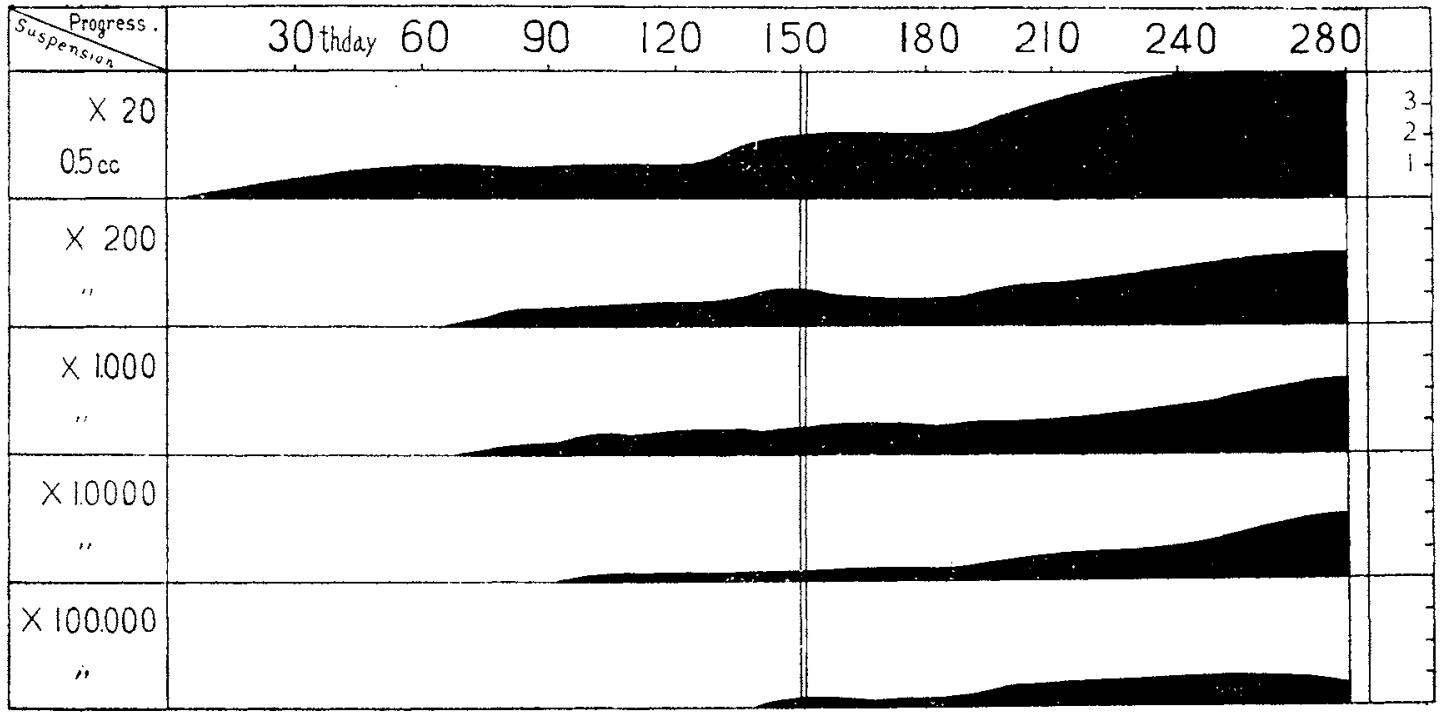


Fig. 3 Development in Control Group.

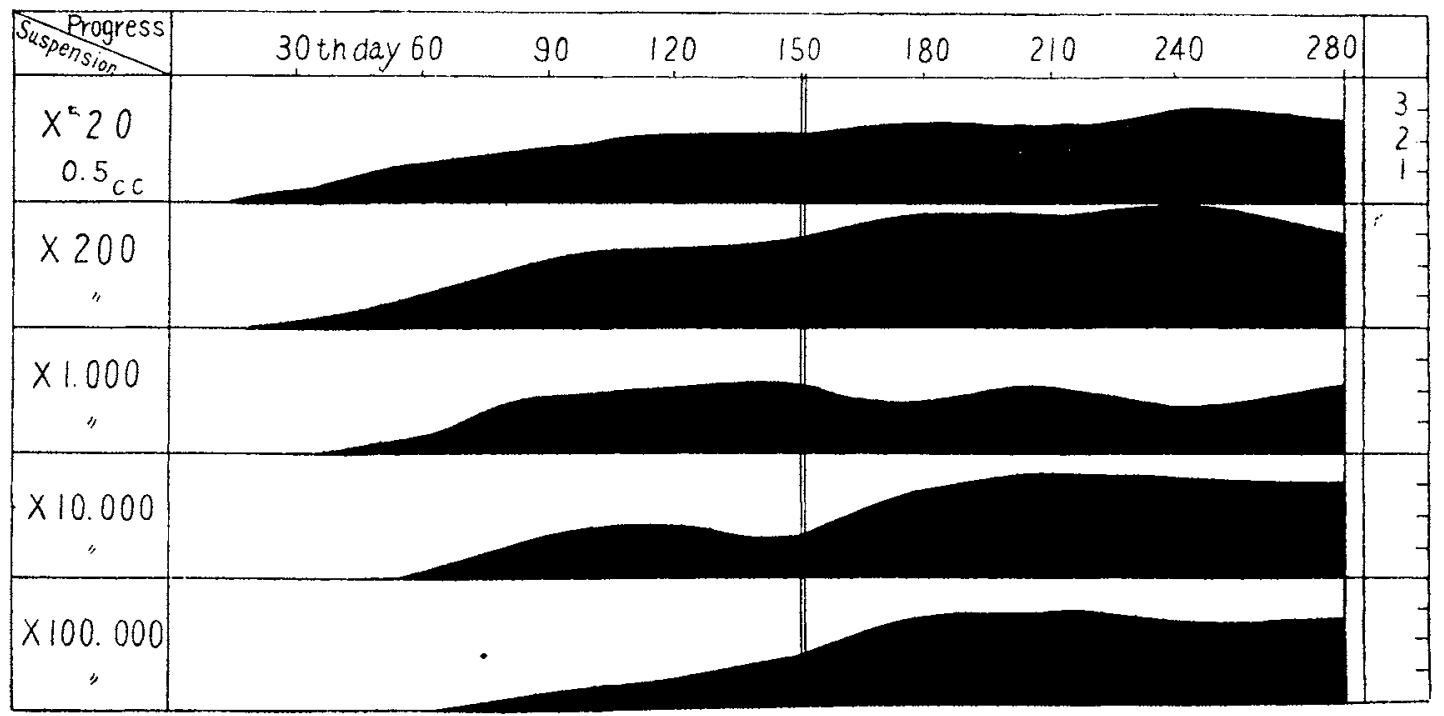

Average of 10 rats for each dilution

Fig. 4

Weight of Leproma

\begin{tabular}{|c|c|c|c|c|}
\hline$\times 20$ & $\times 200$ & $\times 1.000$ & $\times 10.000$ & $\times 100.000$ \\
\hline $1 g \quad 2$ & & & & \\
\hline E & - & & $\square$ & $\square$ \\
\hline 10 & 6 & 0 & 3 & \\
\hline
\end{tabular}

Distribution of Bacilli

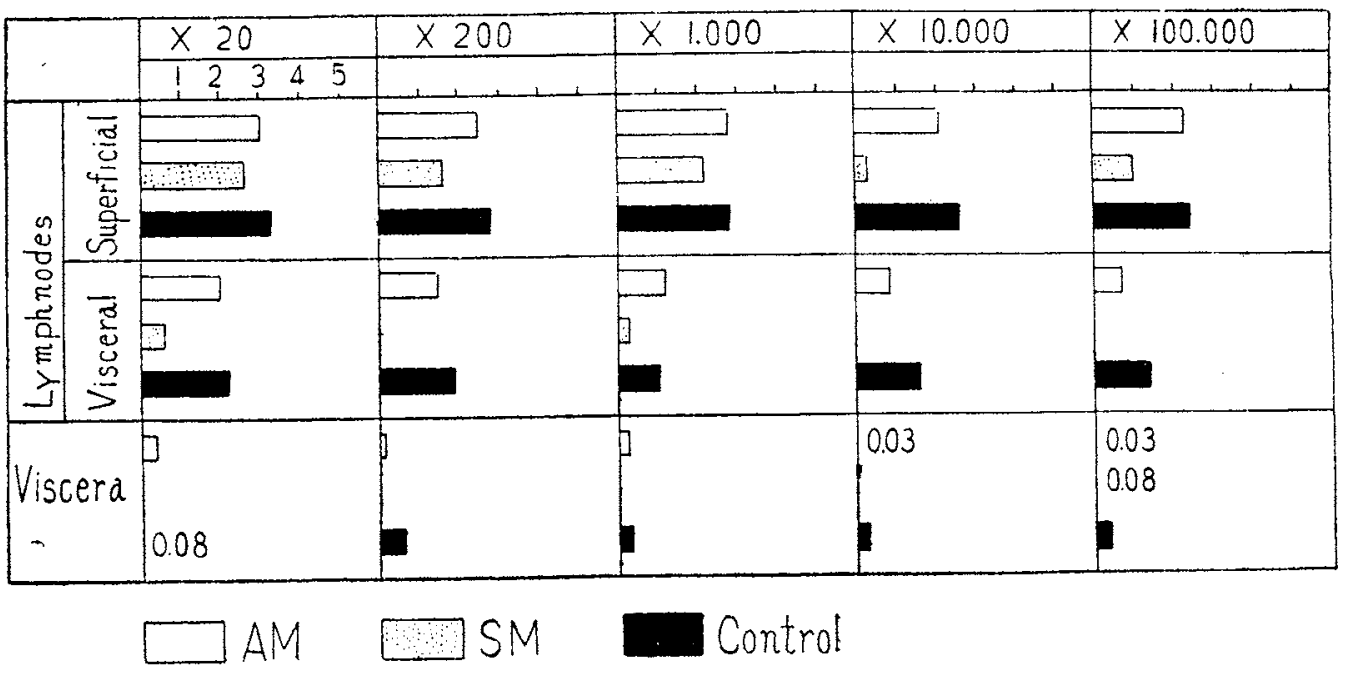


に大であるが，200 倍組以下の各組に於ては何れる SM 群の方が小い。そして $10^{3}$ 倍, $10^{4}$ 倍， $10^{5}$ 倍と潮次接 種菌量の稀薄になるにつれてその差は大となつている。

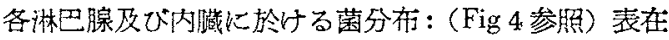
淋巴腺に於てはSM 群も进を涇めてはいるが，対照群に 比して少く，殊に接種菌最の稀薄な $10^{4} ， 10^{5}$ 倍各組に於 ては対照群に比して著しく少い。内墭濑巴腺に於ては対 界群では各組に於て相当数の菌を熹めているにかか和ら

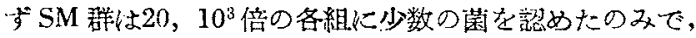
他の組ではこれを見出していない。内做に於ても对照群 では莯㤂認女ているが，SM群では105倍組に於て極少数 認めたのみで他の組では認めていないり上菌分布につ

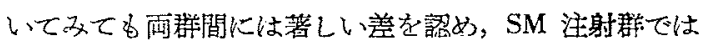
明かに発度が狮制されている。

III Aureomycin ○發症阻止作用

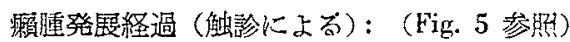

Fig. 5

Inhibitory Action of Aureomycin on Development of Murine J.eprosy

\begin{tabular}{|c|c|c|c|c|c|c|}
\hline & Treated Group & & 01 & Troup & & \\
\hline 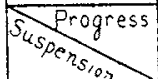 & $\begin{array}{llll}30 \text { thday } 60 & 90 & 120 & 150\end{array}$ & 30 & 60 & 90 & 120 & \\
\hline $\begin{array}{l}\times 200 \\
0.5 c c\end{array}$ & & & & & & $\begin{array}{l}2-1 \\
1-1\end{array}$ \\
\hline $\begin{array}{c}\times 10.000 \\
\end{array}$ & & & & & & $2-$ \\
\hline
\end{tabular}

Average of 10 rats for each dilution (treated group) $\Lambda$ verage of 5 rats for each dilution (control group)

Weight of Leproma

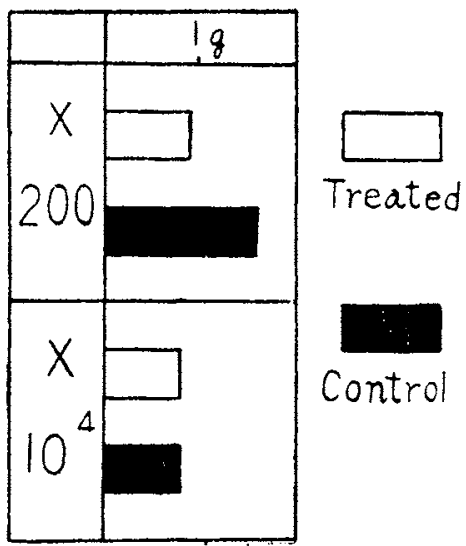

Distribution of Bacilli

\begin{tabular}{|c|c|c|c|}
\hline & $\begin{array}{l}\text { Superficial } \\
\text { lymphnodes }\end{array}$ & $\begin{array}{l}\text { Visceral } \\
\text { lymphnodes }\end{array}$ & Viscera \\
\hline \multirow{2}{*}{$X$} & 1234 & & \\
\hline & & & \\
\hline 200 & & & \\
\hline$X$ & & & \\
\hline$\lambda$ & & & \\
\hline $10^{4}$ & & & \\
\hline & & & \\
\hline
\end{tabular}


先ず 200 倍接種組の投与群10匹，対照群 5 迎つつの成 䋶をみるに両群とも接㯖30日目より浸潤を認め，その後

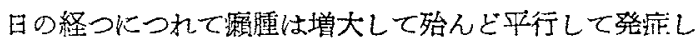
ている。及104 倍接種組の両群についてみても200 倍組 より発症がやや遅延し，阿群ともに60日目より発症し90 日目では投与群の方が発应度は大でるが，その挠 150 月目迄の発症度は两群ともに䀩々平行している。

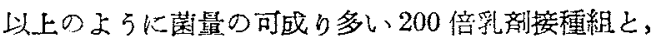

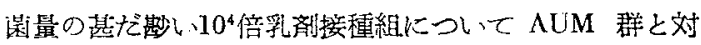
棐群を比較してみて子殆ど平行して発症し著しい相違が ない。即ち AUM，投与の影響は何等認められない。

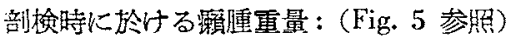

200 倍接種組では投与群の平均重量が対照群よりも小

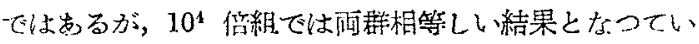
荅。

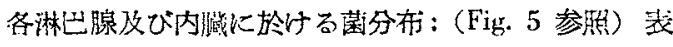
在淋巴腺に於ては $200 ， 10^{4}$ 倍画組と投与群の方が刘

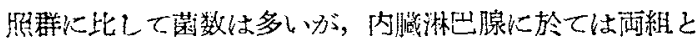
も投与群の力が対照に比して藏教が僅に少い。内胸では

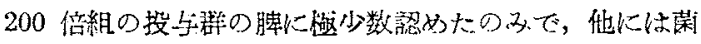

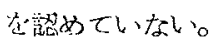

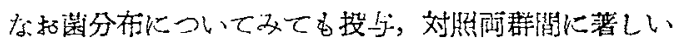

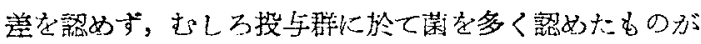
১つた。

以上 3 種の抗生物望炎通して菌形に影響を与元た。の

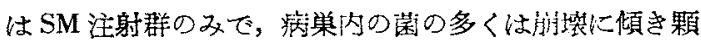

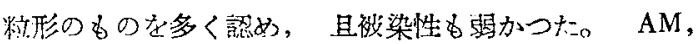

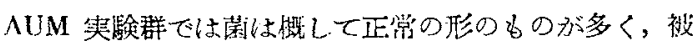

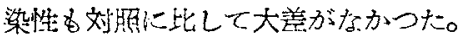

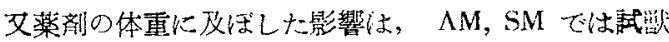

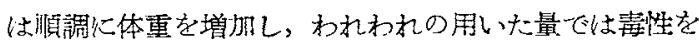
诌めなかつた。AUM では投与 3 週間炟るときは試獣 の体重は減少したので週間休薬して文投薬を繰返した ことは前にも还べた通りでるる。

\section{精括並に考按}

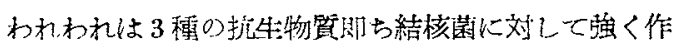
用する Streptmycin と，結核菌には作用しないがリケッ

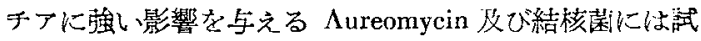

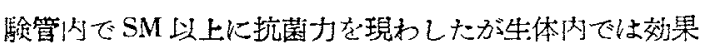

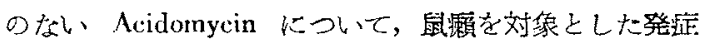
阻止実験を行つて，大体次のよらな事実知ることが出 来た。

1. Acidomycin は鼠䅋の発正を全く阻止し得ない。
2. Streptmycin は鼠磨の登症を可成り阻此し得る。

3. Aureomycin は息瀨の発通を全く阻此し得ない。 以上の事実について考察するに，先ず注目す心゙さこと

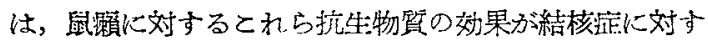

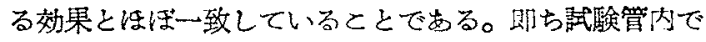
最す强い挖結核菌作用を発揮したAMが，生体内結核菌 には然效に終つているのと同様に，鼠瀨に対しても全く 效果を現していない。AM が生体内ではなぜこのよらに

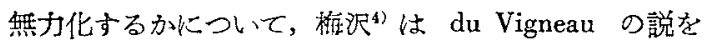
引用して，このbのは赫営内では結核囷の発青に必要 な Biotin (下表) の形成を阻害するととによつて抗䔉作 用を発掩するが，生体内では，生体自身の作るBiotinの ナニめに最旱やとの作用は失和孔るのであると解説してい<smiles>O=C(O)CC1SCC2CNC1ON2</smiles>

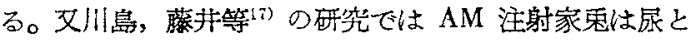
共に Biotin が多量に排淮されるというから，而者の模 造式から洘えて生体内之入つた AM がその杰 Biotin 化して路5といらととも想像されないとともない。百子

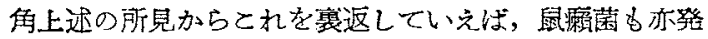
育に必要存物質として Biotin 资献求するものですると 考えてよいよらに思われる。

SM の作用機転についてはい李代明かではないが，

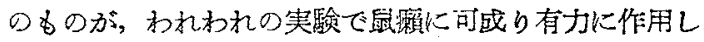

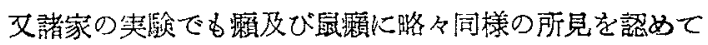

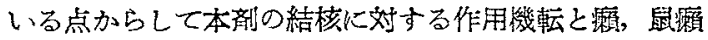
以対する作用㙨転とは共通したところが先ると考完て上 いのてはない洷ららか。

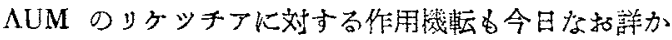

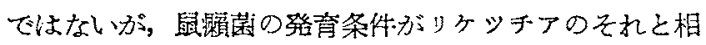
侧ているといらととろから，これ炎試みたのでさつた

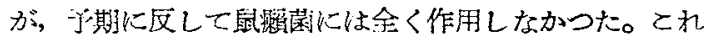
心よると，単に発紊条件が似ているといらだけでは同一 效果を求むるととがむつかしく，やはり菌体そのるのの

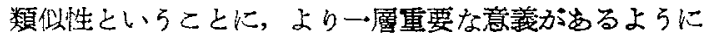

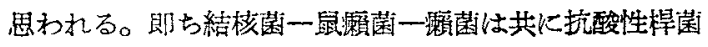
として，全体的ではなが，一部に共通した代謝機能が 黨玉れているものと考えてよいよ5に思う。 


\section{結論}

著者等は Acidomycin, Streptomycin, Aureomycin の

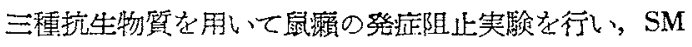
は発症を可成り抑制したが，他の2つは排制し得なかつ た。

そしてとのような事実にもとづいて考按を試み，実験 結核に有効でない抗生物質は鼠瀨の発症阻止にる役立た

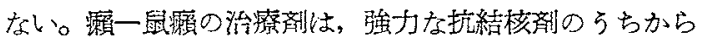
見出されるであろらといら従来のわれわ礼の教它一層 強くするととが出来た。

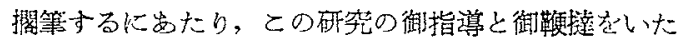
た゚いた名誉教授佐谷有吉先生に悬く御礼电上げはす。

本研究は科学研究費计に大阪結核研究会の援助に上る ところ大である。（浴村）

\section{文献}

1) $\Lambda$ kira Miyake, $\Lambda$ kira Morimoto, Tomoji Kinoshita: Pharmaceutical Bulletin. Vol. 1. No. 1 f. 81. (1953)

2) Akira Miyake, Akira Morinoto, Tomoji Kinoshita: Pharmaceutical Bulletin. Vol. 1. No. 1 p. 8 (1953)

3) Mc Lamor, W. D. Celmer, V. C. Bogert, F. C. Penington, I. A. Solonion: J. A. C. S. Vol. 74 p. $2946 \sim 7 \& 2947 \sim 8(1952)$

4.) 梅沢浜夫：自然 8 巻 2 号 $3 \mathrm{~S}$ 頁 1953 .

5) Faget, Erickson: Intern. J. Leprosy Vol. 15 p. 146 153 (1947)

6) Erickson: Intern. J. Leprosy Vol. 19) 1. 144 (1951)

7) 犀川一夫：医療 7 巻 4, 号工貝 (1951)

8) Grumberg, Schnitzer: Intern. J. Leprosy Vol. 19, p. 520 (1951) より引用。

9) Levaditi, Chaigneau-Erhard: Intern, J. Leprosy Vol. 20 p. 299 (1952) より拥。

10）佐藤三郎，真山処： レプラ 20 卷54頁 (1951)

11) 北村包莨, 谷奥喜平: レプラ20巻55頁 (1951)

12）安元健胃：レブラ21巻23頁 (1951)

13）高山保郎，安元健巟：レブラ22巻18資 (1953)

14.) Chang: Intern. J. Leprosy Vol. 21, No. 1 p. 47, \& 57. (1953)

15）柳沢交德：瑇新医学 5 卷 5 ij (1950)

16) 梅沢純夫：抗莉性物筫 (1954)

17) Kawashima Minoru, Fujii Shizuko:

Pharmaceutical Bulltin Vol. 1. No. 4. p. 328 331 (1953)

\section{THE THERAPEUTIC EFFECTS OF PROETHYL ON THE RAT LEPROSY}

\section{HAJIME NAKASHIMA}

\section{Department of Jermatology and Urology, School of Medicine, Kurume University}

(Director: Prof. S. Shigematsu)

I have studied on the therapeutic effects of proethyl in relation to the development of rat leprosy. The results were as follows.

1) The mortal dose of proethyl is DL $50-93.64 \mathrm{mg} / 10 \mathrm{gr}$ by subcutaneous injection of this drug and DL $50-142.5 \mathrm{mg} / \operatorname{logr}$ by its internal dosage.

2) The density of proethyl in blood was appeared the highest after the internal dosage during 2 hours, and half degrees after 5 hours. This density of proethyl could be measured by 24 hours.

3) The therapeutic effectiveness of this drug on rat leprosy was based upon the degree of the enlargement of leproma and the dissemination of lepra bacilli into tissues. It was appeared a little effect on rat leprosy.

\section{プロエチールの鼠癩治療效果に就て \\ 久留米大学医学部皮虞科泌尿器科学教案 (主任 重 松 教 授) \\ 助手中曷 \\ (昭和28年12月28日受䅧)}

